Forum Kritika: Performance and Domination

\title{
RESISTANT ACTS IN POST-GENOCIDE RWANDA
}

\author{
Ananda Breed \\ University of East London \\ a.breed@uel.ac.uk
}

\begin{abstract}
Performances of justice and human rights have served as international platforms for truth-telling and nation-building both in the aftermath of apartheid in South Africa, and genocide in the case of Rwanda. There are moments of overlap between actual court proceedings, which can in their own right be deemed as a performance, and the use of theatre for dialogic negotiations between past atrocities and present juridical systems for reconstruction. ${ }^{1}$ Within the messy context of post-conflict reconstruction, speech often falters. Articulations of identities and speech acts become disjointed between personal and collective memories and identities; but are forced into the construction of juridical speech in the case of Rwanda's gacaca courts. This essay will analyze how micro and macro sociopolitical dynamics are articulated in the gacaca courts used to adjudicate crimes linked to the 1994 genocide against Tutsi during which over 1 million Tutsi and Hutu moderates were massacred. I will illustrate how these different levels of power interact with each other through social performances (Alexander, 2011) and to extend the concept of faltered speech as artistic resistance (Scott, 1990).
\end{abstract}

\section{Keywords}

genocide, performativity, performance, gacaca, ingando, justice, reconciliation, resistance, human rights

\section{About the Author}

Ananda Breed is Senior Lecturer at University of East London where she co-directs the Centre for Performing Arts Development (CPAD). She is the author of Performing the Nation: Genocide, Justice and Reconciliation (Seagull). Her research examines varied dimensions of performance and performatives in relation to conflict. Breed conducted research and practice related to the use of cultural forms for conflict prevention in the Democratic Republic of Congo (DRC), Indonesia, Kyrgyzstan and Rwanda. A Fellow at the Interweaving Performance Cultures research center, Freie University, Berlin (2013-2014) her project explores applied cultural forms in Central Asia. 
THIS ESSAY WILL ANALYZE HOW MICRO AND MACRO SOCIO-POLITICAL DYNAMICS are articulated in the practice of Rwanda's gacaca courts used to adjudicate crimes linked to the 1994 genocide against Tutsi during which over 1 million Tutsi and Hutu moderates were massacred. I will illustrate how these different levels of power interact with each other through social performances (Alexander, 2011) and to extend the concept of faltered speech as artistic resistance (Scott, 1990). My analysis is primarily derived from fieldwork in Rwanda between 2004-2006 and 2010, noting that performance practices have assumed important and varied roles in the reconstruction project, both official and informal. My focus is on gacaca, and two other forms distinct from, but influenced by gacaca; both the shortcomings of a state-mandated system that declined in public credibility over time not least because of a lack of integrity in relation to procedures for bringing detainees to justice-and its (perhaps unforeseen or unintended) advantages: openness to subversion by faltered speech acts and counter-narratives; begetter of a culture of articulation of grievance and aspiration.

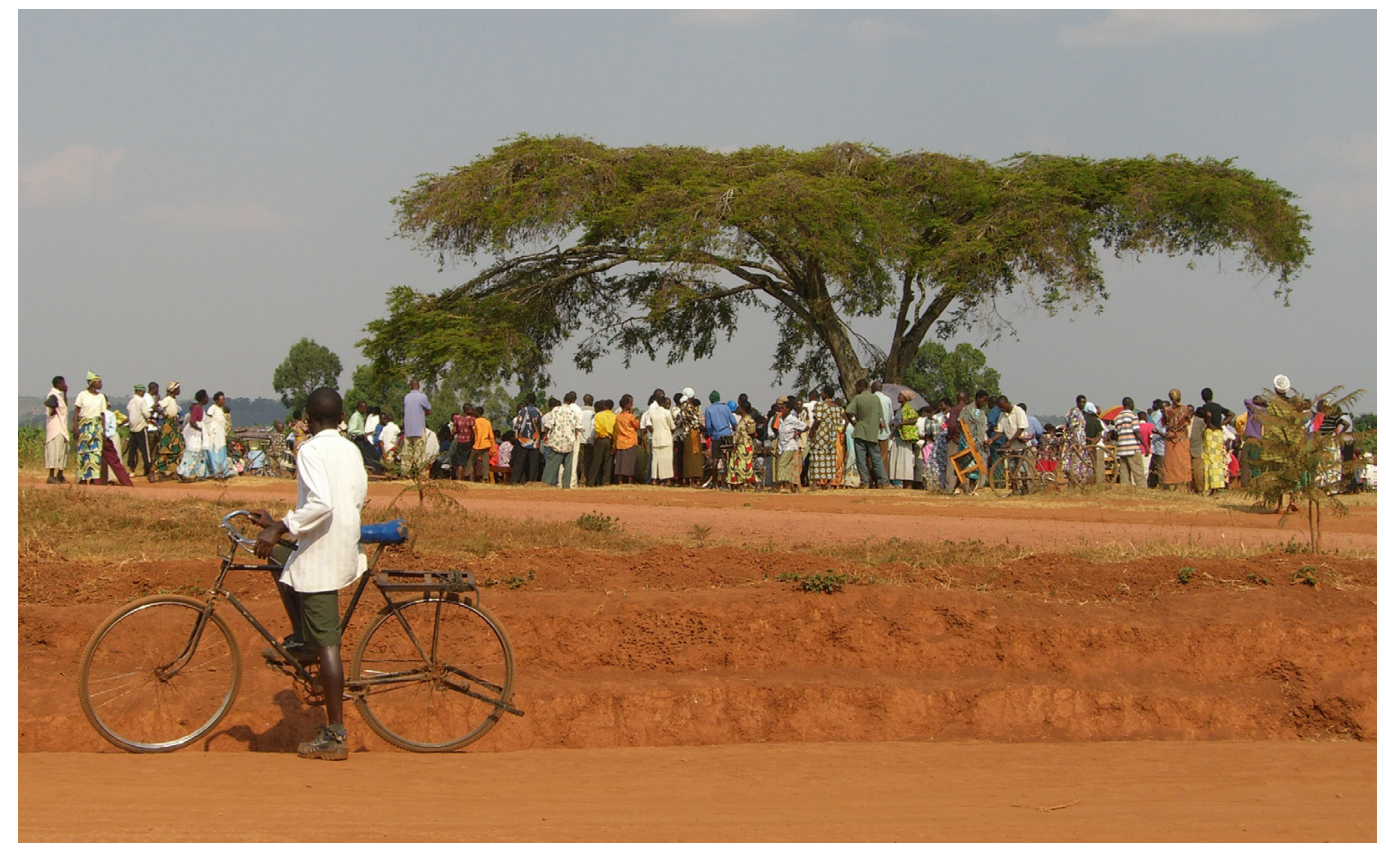

Fig. 1: a gacaca court in session

Performances of justice and human rights have served as international platforms for truth-telling and nation-building both in the aftermath of apartheid in South Africa, and genocide in the case of Rwanda. There are moments of overlap between actual court proceedings, which can in their own right be deemed as a performance, 
and the use of theatre for dialogic negotiations between past atrocities and present juridical systems for reconstruction. Within the messy context of post-conflict reconstruction, speech often falters. Articulations of identities and speech acts become disjointed between personal and collective memories and identities; but are forced into the construction of juridical speech for gacaca courts. James Scott writes about the negotiation between public transcripts and hidden transcripts, the later being, "a critique of power spoken behind the back of the dominant" (xii). Scott notes the significant difference between how individuals negotiate power discourses through varied guises and the concept of speech impediments caused by power relations as faltered speech:

By recognizing the guises that the powerless must adopt outside the safety of the hidden transcript, we can, I believe, discern a political dialogue with power in the public transcript. If this assertion can be sustained, it is insignificant insofar as the hidden transcript of many historically important subordinate groups is irrecoverable for all practical purposes. What is often available, however, is what they have been able to introduce in muted or veiled form into the public transcript. What we confront, then, in the public transcript, is a strange kind of ideological debate about justice and dignity in which one person has a severe speech impediment induced by power relations. If we wish to hear this side of the dialogue we shall have to learn its dialect and codes. (138)

Scott refers to the imbalance of power as faltered speech when "one person has a severe speech impediment induced by power relations" which is a useful analogy to contextualize national performatives related to the implementation of gacaca, between 2005-2012. During several gacaca proceedings that I attended between 2005-2006 and 2010, I observed layers of social performances being played out between the overarching legal gacaca frameworks. In order to identify, analyze and understand the coding of resistant performatives within the gacaca system, this article will address both the performative dimensions of the gacaca courts in Rwanda alongside the theatrical negotiations of justice, truth telling and human rights.

Both the constructed legal space of the gacaca courts and the theatrical space of performance contain or hold transformative power and the possibility for resistant acts. Erika Fischer-Lichte notes the transformative power of empathy within the co-presence of the performance space, deriving from an encounter with otherness. Similarly, the theatrical space offers critical distance to evaluate the political, emotional, and juridical frames of the genocide, and in and of itself, can enable an important political and social event. Fischer-Lichte comments on the transformation from a work of art to an event: 
Prevalent aesthetic theories hardly address the performative turn in the artseven if they can still be applied to it in some respects. However, they are unable to grasp its key aspect-the transformation from a work of art into an event. To understand, analyze, and elucidate this shift requires a whole new set of aesthetic criteria, suited to describe the specific characteristics of performance-an aesthetics of the performative. (23)

The term performative was coined by J.L. Austin to account for the linguistic power of words, or utterances in which words have the power to create that which they name as in the case of the marriage vow "I do" whereby two people become legal subjects of husband and wife. In relation to earlier work, I've stated that the post-genocide subject has been created through performatives related to Rwandanicity, or the construction of a unified Rwandan subject devoid of ethnic identifiers. ${ }^{2}$ However, the resistant acts that I will refer to in this article pertain to the liminal space between the "utterance" and the "coming into being." In this way, the whole of the nation is in a state of transformation from the event to the art (or performance) of the new Rwanda. Although, my emphasis on the transformation from the event to the art (or performance) is the reversal of Fischer-Lichte's formula, I'd argue that social performances are often framed between one or the other and that the balance between which direction the transformation occurs is more like the structure of an hour-glass that can be over-turned, rather than encompassing a unilateral direction or process.

The reconstruction of Rwanda has been referred to as a social engineering project through "transformative authoritarian" intervention (Straus and Waldorf 5). In this case, the government seeks to create a new Rwanda as rehearsed through ingando solidarity camps attended by university students, released prisoners, and returned refugees and performed through speech acts that serve to bring into being Rwandanicity. However, I focus on acts of resistance that take place within the gacaca's liminal, transformative space, to help direct speech acts towards events or performances that negotiate the "transformative authoritarian" construction of identity, in relation to the lived reality that moving from genocide to a unified Rwandan identity requires acts that may run counter to governmental practices or policies.

\section{Political Constructions of Identity}

In order to address how resistant acts are performed in Rwanda, it is important to classify how and why these acts might be deemed as acts of resistance and against what factors. Currently, the Government of Rwanda is primarily led by members of the Rwandan Patriotic Front (RPF), which has historically been identified as Tutsi under the leadership of President Paul Kagame. Following the 1994 genocide, there have been strict laws embedded into the constitution by the Government of 
Rwanda that promote social cohesion to the exclusion of ethnic identifiers. The logic being, that the division between the Rwandan ethnicities of Hutu, Tutsi and Twa developed prejudice and animosity (enforced through divide and rule tactics of Belgian colonization) and that ethnicity would need to be erased in favor of a unified Rwandan identity for peace to prevail. However, ethnic identities were heightened during the gacaca proceedings, as people recounted events during the genocide and recovered memories from a time period in which someone's identity could mean either life or death. The ethnic labels Hutu and Tutsi eventually became synonymous with "perpetrator" and "survivor," which will have a grave effect on rwandanicity (Pottier 130). In one case, the government prescribes a national identity devoid of ethnic labels and on the other, ethnic identities return as a kind of performative haunting by the embedded constructions of ethnic identities leading up to the genocide.

Resistant acts are related to how local communities negotiate the multiple contradictions of rebuilding communities and judging genocidal crimes through a national campaign aimed towards a unified Rwandan identity, in the midst of the performative haunting of ethnic identities. During gacaca proceedings, community members are expected to speak out openly about the events during the genocide, to provide testimonies either in defense or prosecution against the accused and for a limited few to serve as the local judges or inyangamugayo (persons of integrity). Although there are general gacaca laws that mandate protocol for court proceedings, the narration of events and interplay amongst different communities and regions can be widely divergent. Thus, how do individuals actively address prejudice and injustice? How do communities discuss problems within the current juridical and government structures when Rwanda is effectively under the authoritarian rule of a dictatorial government? For the purpose of this article I will

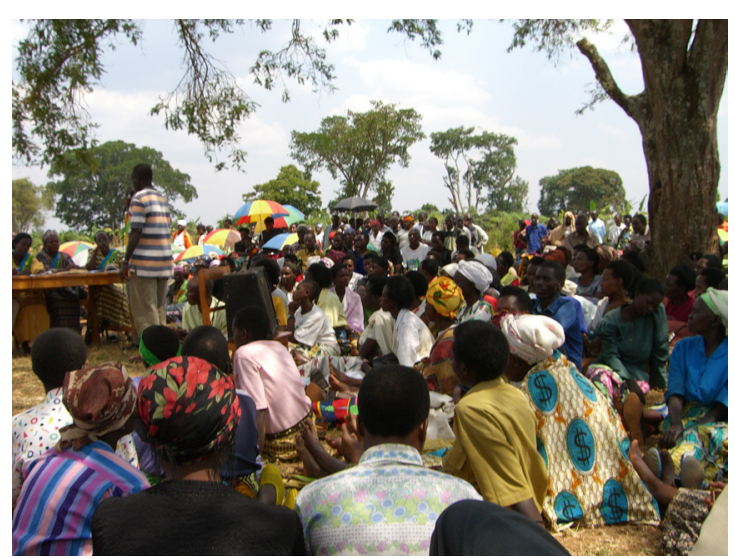

Fig. 2: an accused person testifies before inyangamugayo (persons of integrity) in a gacaca court address moments of intervention, when theatrical or performative mechanisms have been used as sites of resistance by adapting, but not violating the conventions of gacaca, and highlight the importance of resilience within acts of resistance. I proceed to analyze the gacaca courts as a social performance, and then to examine examples of alternative performances and resistant acts, which I will argue deconstruct the government's identitarian project while remaining within the conventions of gacaca. 


\section{Gacaca as a Social Performance}

James C. Alexander provides a performance framework to address the varied relations of power and conditions for social performances. Alexander claims that every social performance combines some or all of the following six components: actor, collective representations, means of symbolic productions, mise-en-scène, social power and audience. I will use this framework to explore how gacaca courts could be framed as examples of social performance, since the structure of gacaca was inherently scripted, rehearsed, and performed to create Rwandanicity. Brigadier-General Frank K. Rusagara, a journalist from the Rwandan newspaper The New Times states:

The concept and institution of the gacaca justice system comes through as one of the most enduring in Rwanda, not only in conflict management through restorative justice, but in serving as a lubricant to the ideology of rwandanicity that ensured unity and cohesion in the society since the pre-colonial times. By definition, rwandanicity was an idea and a philosophy that guided the people's conduct and perceptions. As an ideology, therefore, it is what the people of Rwanda understood themselves to be, what they knew about themselves, and how they defined and related to each other and their country as a united people (Ubumwe). Thus, other than giving identity, rwandanicity is also the medium in which Rwandans got their worldview. (1)

The military title of the journalist is worth noting based on the historic function of the military to coordinate Ingando solidarity camps for the indoctrination of RPF ideology. Chi Mgbako challenges the notion that the ingando existed in precolonial times, highlighting instead the role the RPF has played in bringing to prominence the idea and use of ingando since coming to power:

While the practice of elders gathering together to address challenges facing the community is present in Rwandan culture, there is little indication that this practice was ever called 'ingando.' Ingando is more likely a pre-war RPF creation aimed at grassroots mobilization for RPF campaigns. From 1990 to 1993, the RPF installed participants in ingandos or 'RPF schools' for three weeks, after which participants would be expected to return to their villages and disseminate pro-RPF ideology. This RPF practice may have occurred in Uganda and RPF- controlled territories in Rwanda. In addition, the RPF, whose ideological mentor is Yoweri Museveni of Uganda, may have modeled ingando on solidarity camps in Uganda. (Mgbakon 208)

Military links between how the ideology of Rwandanicity becomes institutionalized through Ingando indoctrination campaigns and the reimagining of 
gacaca from pre-colonial times is an important correlation to understand. Further, how the arts have been used as a functional tool for the establishment of society as part of the construction of Rwandanicity for both Ingando and gacaca. During Ingando camps, songs and dances are used for the recitation and embodiment of lessons based on the history of Rwanda and development aims. Theatre was used as a vehicle for the sensitization and mobilization of gacaca, to educate and to rehearse the population for the courts (as many had never seen nor heard of gacaca prior to its implementation in 2005). In regards to the integration of the arts within Rwandan society, the National Unity and Reconciliation Commission (NURC) stresses the role of the arts for socialization or transformation stating, "[i] n pre-colonial Rwanda art did not only "mean" it also "functioned"... some of this art reinforced the values of the society, and socialized the young into the culture of the people."

I will use Alexander's framework to encode gacaca as a social performance, providing examples of how gacaca adheres to (or doesn't adhere) to the form. The sections in italics come directly from Alexander's own writing, with my own observations below.

1. Actor. This could be an individual, a group, an organization, and may reference any level from casual and unstructured flow to class, gender and national conflicts, such regional identities as Europe, or processes in the global civil sphere. Actors can be skillful or not, lifelike or wooden, imaginative or dull (Alexander 83).

The actors of gacaca could be deemed to include every Rwandan citizen, since the participation and attendance of citizens was mandated by law. However, if we are to structure actors as listed above, individuals might include women, men and children. I've observed attendees from between several months old to elders in their nineties. Actors could be positioned along varied social and legal structures, including the roles of perpetrator and survivor. Alexander notes the agonistic component of social performances, "[t]he better the script, the more it is agonistic" (85). Nigel Eltringham interprets the government's use of the terms perpetrator and victim as synonymous with Hutu as perpetrator and Tutsi as victim (7299). Citing Eltringham, Lars Waldorf emphasizes the impact of accusations on the unification of Rwanda stating, "[o]verall, gacaca imposed collective guilt by generating accusations of genocide against perhaps one million Hutu - a quarter of the adult Hutu population"(19). Thus gacaca has reinscribed the ethnic labeling of the past (Hutu-Tutsi), using new labels (genocidaire-victim) (see Eltringham 2004: 72-99) (Waldorf 200).

Within the structure of the gacaca itself, actors include government security, gacaca officials, occasional trauma counselors, and observers and researchers from international organizations and academic institutions. Attendees often include 
representatives from associations like AVEGA Agahazo, the association of the Widows of Rwanda, or varied grassroots associations that have used the arts to bring members of their communities together. ${ }^{3}$ Subsidiary organizations can be highly structured and linked to the government such as the National Unity and Reconciliation Commission (NURC) and the National Service of Gacaca Courts (SNJG) to administer gacaca laws and jurisdictions, alongside international monitoring organizations including Penal Reform International (PRI) and Advocates Sans Frontieres (ASF). The actors involve local, provincial, national and international level players.

2. Collective representations. The languages actors speak are multiple, and the words and phrases that come out of their mouths are singular, but they are speech acts, not languages in the semiotic sense. Each speech is a play upon the variations of a background structure, the collective representations that define the symbolic references for every speech act...(Alexander 83)

The gacaca is performed in strict adherence to gacaca laws and the functioning of gacaca courts. According to Gacaca Law No. 16/2004 of 19/6/2004, the accused must provide a confession in order to be considered for release as stated in Article 54: Apologies shall be made publicly to the victims in case they are still alive and to Rwandan Society. To be accepted as confessions, guilty plea, repentance and apologies, the defendant must: (1) give a detailed description of the confessed offence, how he or she carried it out and where, when he or she committed it, witness to the facts, persons victimized and where he or she threw their dead bodies and damage caused; (2) reveal the co-authors, accomplices and any other information useful to the exercise of the public action; (3) apologize for the offences that he or she has committed (15). How well prisoners performed their acts of contrition won them freedom or subjected them to further time in prison. ${ }^{4}$

In terms of how "each speech is a play upon the variations of a background structure, the collective representations that define the symbolic references for every speech act," the gacaca builds upon Judeo-Christian ideologies related to forgiveness and contrition as a construction of sovereignty enacted on an individual as part of juridical procedures for crimes against humanity. Within the gacaca proceedings, the confession must be presented as part of the juridical requirement.

3. Means of symbolic production. In order to communicate such foregrounded representations, actors need real material things, which are themselves, of course, meaningfully defined. For the messages of an actor to be projected, they need a stage, whether this is a place in the sand, a tree or a high spot of ground, a newspaper, television transmission, video cam, or website. Performers also need props, which can be a parrot beak, full costume regalia, 
background music, spotlight, or the semi-automatic rifle cradled casually in one's arms. (Alexander 83)

The judges wear a sash with the title Inyangamugayo across their chests, with the colors of the Rwandan flag: green, yellow, and blue. Inyangamugayo carry the paper booklets of gacaca laws in their hands as props, which they refer back to throughout the court proceedings, and often lift into the air as if indicating power through the handling (and knowledge) of the contents. According to Mughisha, the performance of knowledge and power is additionally a performance of their literacy levels, which stands nationally at 69.7 percent. The stage has been referred to in the name gacaca itself, referring to a grassy place. Gacaca can be conducted in the grass, and usually underneath the shade of a tree, but can also be located in community buildings, government buildings, or structures designed with corrugated metal and plastic tarp to provide shelter. Security guards are costumed in burgundy uniforms and carry automatic rifles, located near or outside any entrances/exits with an overview of the space. The prisoners wear flamingo-pink uniforms. The secretary, one of seven Inyangamugayo, transcribes court proceedings. As many citizens are illiterate, both accusers and accused place their thumbprints on documentation to confirm accuracy.

4. Mise-en-scène. Literally "putting into the scene," this French phrase has come to represent what directors do. It is the arranging and the doing, of actors' movements in time and space. It is the tone of voice, the direction of the glance, the gestures of the body, the direction and intensity of the spot lighting. (Alexander 83)

If we are to regard the state, in the person of President Paul Kagame, as the prime director then the arranging of actors' movements is based on the enforcement of power. Perpetrators are released from prison after admitting guilt and are brought to the gacaca in government vehicles. The arrival of the prisoners is a part of the mise-en-scène, followed by the entrance of the Inyangamugayo into the courtroom setting (whether that be a grassy field or government building). In several gacaca courts that I attended, the Inyangamugayo enter the "stage area" in single file and the community actors or attendees stand. The accused is called to the presiding desk of the Inyangamugayo and the primary discourse is between the President of the Inyangamugayo of each court and the accused. The accused customarily bows his or her head in an act of contrition, and holds his or her arms behind his or her back. The President carries an authoritarian persona; often displaying aggravation or sharp tone of voice, when the accused denies charges or appeals the case.

5. Social Power. This dimension of social performance, often invisible, is critical in making the elements of performance available, or not. It can be defined 
as resources, capacities, and hierarchies, but it involves also the power to project hermeneutical interpretations of performance from outside political and economic power narrowly defined. (Alexander 83)

Gacaca was manipulated for individual and social purposes following the mandate to speed up sentences in 2007 and the ineffectiveness of both national and international organizations to monitor and control the fairness of justice. Astrid Jamar states, "[r] egardless of warnings, the Organic Law No. 10/2007 of 01/03/2007 added a total of 2215 Benches, and reduced the number of judges required to achieve this goal. An ASF analytical report affirms that the acceleration of trials impacted seriously on the fairness of justice" (85). The inability of the government and gacaca monitoring agencies to manage fairness within the courts potentially sets the stage for an aftermath of structural violence due to reparations, financial instability for those serving community service or prison sentences, and limited financial support for survivors. I've commented on the space between the frameworks of gacaca law and what actually occurs within the gacaca courts, and the potential disintegration of law through law itself (as noted above). Here I borrow from the work of Stephen Humphreys to portray gacaca as an instrument for the state of exception in post-genocide Rwanda. Humphreys citing Giorgio Agamben states: " $\mathrm{t}]$ he state of exception is today codified in international law through the notion of derogation. When faced with a public emergency that 'threatens the life of the nation' international human rights treaties-and many constitutions-permit states to suspend the protection of certain basic rights. In practice, the derogation model 'creates a space between fundamental rights and the rule of law, wherein states can remain lawful while transgressing individual rights" (qtd. in Humphreys 678-679). In this way, the genocide and the perilous condition of Rwanda post-genocide created a state of exception, through which individual and social agendas can be manipulated through gacaca both within and outside the law. During numerous gacaca court sessions that I attended between 20052010, I observed how the ability of Inyangamugayo to adjudicate cases effectively was largely reflected in apparently predetermined judgments, often transgressing individual rights. The President of the gacaca often questioned the accused under presumption of guilt and summoned testimonies of support. Considering that Inyangamugayo are given four days of training in total, their lack of competency to use evidence, to cross-examine, and to adjudicate gacaca effectively - might be based on hindering of judgment due to the traumatization or retraumatization of inyangamugayo from the weekly witnessing of testimonies related to the genocide. Humphreys states,

... application of law by judges is, like speech, an enunciative act that applies the general to the particular. But just as speech acts can fail to connect with actual phenomena, circulating instead in the abstract self-referentiality of 
langue, similarly, law can be applied without explicit recognition of any reality outside its own abstract realm. (682)

The social structures within which genocide was enacted and gacaca was implemented were not adequately addressed through gacaca laws. Social constructs, like the original use of gacaca for community mediation of low-level crimes, take into account social power and local power discourses. However, the re-invention of gacaca for genocide crimes does not take into account the difference between national performatives concerning justice and reconciliation and what's really happening on the ground, thus law "applied without explicit recognition of any reality outside its own abstract realm" and subject to manipulation.

6. Audience. All of the above become significant only insofar as they allow or prevent meanings from being successfully projected to an audience. Audiences are placed at different removes from actors, and they can be more [or less] homogenous or divided. (Alexander 83)

Rwanda relies heavily on international aid (indicating international audiences) and thus, much of its rhetoric repeats international slogans like justice and reconciliation as tropes, but there are inherent differences between how Rwanda performs for the international community and how power and resources are negotiated within Rwanda. ${ }^{5}$ In terms of international audiences, there are donor communities like the European Union (EU) who largely support the overall budget in Rwanda by over $58 \%$ of Rwanda's official development assistance (ODA). Filip Reyntjens notes the significant power of the RPF to silence any outside contestation as a systemic defense tactic that relies on "genocide currency" to have successfully shut down human rights organizations, enforced a one-party dictatorial government, and effectively ignored recommendations provided by gacaca monitoring agencies including Penal Reform International (PRI) and Advocates San Frontier (ASF). Thus, foreign investment in justice and reconciliation may actually be used towards the RPF version of justice and reconciliation that may not align with international standards of human rights. Reyntjens writes, "[o]n 9 February, Reuters correspondent Christian Jennings was expelled, apparently for having written two days earlier that, during a press conference, (then VicePresident) Kagame had asserted that 'Rwanda has the right to divert a part of international aid to contribute to the internal war against Hutu extremists"'(4). However, the alignment of the RPF with western powers (including inclusion into the Commonwealth) has been an important tactic to hold and maintain power in Rwanda. Thus, performances like gacaca are tightly controlled and curated by the RPF for international audiences. 


\section{Resistant Performatives}

Although I have framed the gacaca as a social performance, it is difficult for performances to actually manifest the new Rwandan identity, without suppressing underlying ethnic and political identities. Alexander states, "[ $\mathrm{t}] \mathrm{o}$ be really powerful means that social actors, no matter what resources and capacities they possess, must find a way to make their audiences believe them"(89). But, what happens if the performative isn't complete? In regards to J.L. Austin's linguistic notion of speech acts and the perlocutionary effect, what would be the psychological consequences of the utterances related to the performativity of Rwandanicity through gacaca? Resistant performatives emerge as counter-performances.

By exaggerating their compliance to the point of mockery, they openly showed their contempt for the proceedings while making it difficult for the guards to take action against them. (Scott 139)

Following the genocide, the prisons were over capacity. One reason for the development of the gacaca court system was to speed up the trials. The first trials to be heard were for those who pleaded guilty, last would be for those who claimed innocence. Thus, many of those who pleaded innocence are still in Rwanda's jails. Here, I will provide an example of resistance in relation to coopting the performative space of gacaca by restaging the social performance that I indicated in the last section. In this case, a prisoner was released after completing the compulsory request to list the names of those whom he'd killed alongside any accomplices. On the day of his public trial, the names of those whom he'd killed were read aloud. But, there was commotion in the court as people rose to state that they were indeed alive, and that they hadn't been killed by the accused. The accused (who had previously claimed innocence) took on the pre-ordained role of the guilty party asking for forgiveness and staging the government script, but inherently performed his innocence through the arbitrary inclusion of names for those whom he'd killed (but were exclusively alive). The accused staged the public transcript to the point of mockery, using the gacaca system itself as the vehicle to perform the arbitrary and contradictory nature of procedures for the release of prisoners. In reference to Scott, the accused was able to "discern a political dialogue with power in the public transcript"(138). While I've primarily focused on the transformation from the event (gacaca) to the art (or performance) in this last example, the following two examples focus on the art (or performance) to the event. The next case study is based on the use of theatre to explore contemporary political and social problems in Rwanda, derived from artistic endeavors by grassroots association Association des Jeunes pour la Promotion du Développement et de la Lutte Contre la Ségrégation (AJDS). In this way, uncovering what Scott refers to as 
the hidden transcript that is often in muted or veiled form ...to learn its dialect and codes (138).

\section{"Amakimbirane Yabaye Urwango" (The Conflicts Become Hatred)}

Grassroots association AJDS was formed under the umbrella association Dufatanye Inshuti Z'Abana (DIZA) meaning "Friend of Children" since 1997, originally set up to support orphans. One hundred and seven children are members of DIZA, of which fifteen are part of AJDS. Since my original encounter with AJDS in 2005, there have been changes to how they function as an association (or not) due to political and social pressures. According to Laurence Mukayiranga, Acting Director of Peace Building and Conflict Management (NURC), associations have been guided towards creating cooperatives, linking unity and reconciliation with development goals: "The development program for the government commission focused on training associations, but not on poverty reduction. Associations need development, they need to produce as part of the national policy to become a cooperative at a district level." Although associations previously worked independently, soliciting for individual project grants, the new scheme requires associations to join a forum on a district level to develop a cooperative project plan with other regional associations. In order to join cooperatives, associations must provide bank account statements and demonstrate sufficient funding. Associations such as Association des Jeunes pour la Promotion du Développement et de la Lutte Contre la Ségrégation (AJDS) claim that the new government cooperative scheme has adversely effected their ability to produce plays based on regional issues. Some members have gone to school, moved to Uganda, Democratic Republic of Congo (DRC), or bordering countries. Most are part of the host organization, and then come together at various points as AJDS. However, it has been difficult to produce theatre because of financial issues and the exclusion of funding for grassroots associations unless registered as a cooperative. Thus, the government has been able to regulate which grassroots associations are given permission to organize, and which are to be disbanded.

Fred Kabanda, the main director and playwright, wrote Icyodupfanakiruta Icyub Dupfa (We Have Common Needs) and Amakimbirane Yabaye Urwango (The Conflicts Become Hatred) in 2009. While in Uganda, he witnessed problems concerning discrimination, especially based on what he noted as "tribalism and religion" illustrated in Icyodupfanakiruta Icyub Dupfa (We Have Common Needs). The other play, Amakimbirane Yabaye Urwango (The Conflicts Become Hatred) is about land issues and how false accusations were made in gacaca to gain material wealth. At the time of my interview with Kabanda, during the culminating period of gacaca in 2010 (although gacaca courts officially ended in 2012 marked by the closing ceremony speech by President Paul Kagame on 18 July 2012) new accusations 
were being made that hadn't been filed previously, potentially as extortion. Both plays are works in progress as hidden transcripts, not yet performed for public audiences other than for informal rehearsals with select audience members. In order to analyze how Kabanda used theatre as an act of resistance to explore current political and social challenges in Rwanda and to understand the codes and dialects of hidden transcripts, I will provide a brief overview of Amakimbirane Yabaye Urwango (The Conflicts Become Hatred) as written by Kabanda in the form of a synopsis (as narrated by Kabanda):

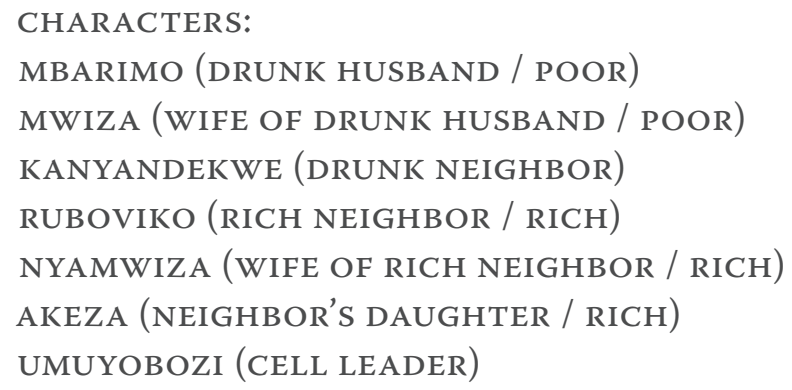

SCENE ONE: Mbarimo and Kanyandekwe enter drinking banana brew curwagwa out of a calabash (gourd). They discuss current issues, including recent community meetings concerning gacaca courts, and remark upon how some people who may be guilty have not yet been tried in gacaca courts. Mbarimo's neighbor, Ruboviko, enters and there is a dispute between them about the pumpkin patch located between the boundaries of their properties. Ruboviko has been harvesting the pumpkins. Mbarimo vows to kill Ruboviko if he continues harvesting from his land. After Ruboviko exits, Kanyandekwe tries to counsel Mbarimo not to allow pumpkins to get between neighbors.

SCENE TWO: Mbarimo calls to his wife Mwiza to prepare food, and exits. Ruboviko calls on the house of Mbarimo, but finds him gone and speaks to Mwiza, asking his whereabouts. Mwiza dismisses him, and complains that his wife Nyamwiza has been abusive. She states that the family of Ruboviko is rich, that they flaunt their expensive clothing, and now that they steal their land to harvest pumpkins. Ruboviko tries to explain and seeks dialogue with Mbarimo, but Mwiza continues to quarrel. Ruboviko leaves, ensuring that he will be back.

SCENE THREE: Ruboviko and Nyamwiza talk about community issues, and problems concerning the closure of gacaca courts, that community members are starting to file cases that had not been heard previously. He states that up to now, the gacaca has been operating for eight years for issues to be raised, why wait until the courts are closing? They discuss how people are now testifying due to hatred, revenge, and personal interests. Ruboviko claims that Mbarimo is spreading rumors that Ruboviko may have had involvement with the genocide. Naymwiza claims that the Mbarimo family is jealous due to their wealth and 
that they want to put them into prison so that they can suffer. Ruboviko states that he is going to the cell (every one hundred households) leader to report that Mbarimo is making false accusations.

SCENE FOUR: Ruboviko, Nyamwiza, and Akeza are eating dinner, when Mbarimo, Mwiza, and Kanyandekwe appear at the home of Ruboviko. Their intention is to attack, but the cell leader appears and intervenes. The cell leader, Umuyobozi, asks them why they are fighting and appeals for them to discuss their problems. Umuyobozi accuses them of creating insecurity, and reminds them about the roots of the genocide, poverty, and security issues. Umuyobozi tries to instill ideologies about development, and how they should be developing themselves versus wasting their time fighting. The individuals involved understand that their leader is speaking the truth. Following, Ruboviko states that he has abandoned the pumpkins and will leave the pumpkins to be harvested by Mbarimo, if he desires. Mbarimo states the same claim, in return. They decide to leave the pumpkins on the boundary, embrace one another, and separate amicably.

The short synopsis provides some detail based on current political and social issues in Rwanda. As espoused by the cell leader, Umuyobozi, conflicts are often created by poverty. The play illustrates how false accusations and court cases were filed in the closing years of the gacaca for numerous reasons including jealousy, property rights, revenge, and lack of security. Although the play ends with reconciliation, the initial problem is not resolved in terms of land issues and one family being from a different socio-economic sphere. I would speculate that alternative solutions could have been illustrated such as harvesting together and splitting profits, but perhaps this outcome would not be realistic and/or the playwright Kabanda might have wanted the audience to come up with their own solutions to the staged problem. In this case, the example illustrates hidden narratives counter to government-driven public narratives. As mentioned within the section based on social performances, any utterances are tightly controlled by the government, whether literally scripted (in the case of a theatrical script) or policed by gacaca law and the day-to-day administration of civic life. Kabanda used theatre to illustrate the disintegration of gacaca, providing an alternative representation of civic life than the predominant government public transcript. In this example, Kabanda illustrates problems that have manifested from gacaca and otherwise but within the safe confines of a theatrical script (not performed for a public audience). In reference to Scott, this could be referred to as a voice under domination: "While nothing like a full analysis of voice under domination is possible here, we can examine the ways in which ideological resistance is disguised, muted, and veiled for safety's sake" (137). But how can the arts be used to create an alternative space for expression in an otherwise tightly controlled dictatorial regime? This question is addressed in a case study provided by the work of Carole 
Karemera, Director of Ishyo, who exemplifies the potential for the hidden transcript to come into dialogue with the public transcript.

\section{Restaging Culture (Carole Karemera)}

The Ishyo Cultural Centre is located at the Goethe Institute in the capital city of Kigali with a range of facilities for a Performing Arts venue including a theatre space, rehearsal and dance studies, café and bar, and administrative offices. There is a large open deck in front of the main entrance where people congregate. This is where I met with the company on several occasions in April 2010 to discuss the objectives of Ishyo and the politics of performance in post-genocide Rwanda. I was struck by the company members' openness concerning the need for the arts to respond to current socio-political issues and their desire to engage wide audiences. Ishyo has addressed sensitive issues in Rwanda since its inception in 2005 , including corruption and homosexuality. They deliver arts to public audiences through a series of tactics, from guerrilla-style theatre distributing theatrical performances in varied public venues like restaurants to a biblio-bus that provides theatre-in-education performances to youth. Ishyo developed the biblio-bus for primary schools, delivering over nine short plays a month. Karemera stated, "[w]e are currently adapting a Russian play by Gogol about corruption. In this way, the situation in Rwanda today is parallel to Russia about 70 years ago. People should be free to talk about what is on their mind. We don't want to work on plays based on reconciliation, genocide or HIV/AIDS." Ishyo stages their productions in different languages including English, French, and Kinyarwanda. Karemera continues, "[i]f for example, there is an English school, we will perform in French. If it is a French school, we will perform in English. People should be curious about language, not to be caught up in political issues concerning language." This comment refers to the ongoing controversy between France and Rwanda due to the role that France played during the genocide by supporting the previous Francophone government of Rwanda through Opération Turquoise and the current Anglophone government of Rwanda led by the RPF. In this way, Karemera notes the significant role of the arts to challenge current themes and issues related to conflict and both ethnic and international tensions.

Leading up to the genocide, radio and theatre were used to legitimize the ideology of genocide, to represent the Tutsi as Inyenzi cockroaches with tails. Thus, Karemera believes it's important to use theatre for different kinds of expression, but that timing is important. In one instance, they presented a play about events in Sudan as a public performance in a restaurant, but the patrons left the venue and the restaurateur told Ishyo never to do a sad play again, that it ruined their business. Now, they use comedy as a vehicle to communicate issues, because people want to continue talking about plays that open up dialogue through laughter. Regarding the influence of gacaca on the performing arts, Karemera stated: 
As a culture, we don't usually talk about personal things. In gacaca, there is an emphasis on truth telling and listening, which is not a part of our culture. Now through gacaca, this platform exists. People will tell a stranger their issues, which would never happen before, or to talk openly about problems. A new culture has emerged to speak freely. People are talking openly about horrible events, including something like rape that would have previously been blamed on the woman, but is now categorized as a criminal act of war. Gives people security to feel protected. People will speak openly on radio program or oppose the Minister in a Sunday program called Cross-Fire which is a kind of confrontation, hard talk-to speak openly. People know if they speak loudly, people will listen. Women didn't speak openly in public before, but in gacaca, most of those who give testimony are women. Now, women have learned to express openly.

Ishyo illustrates the ability to nurture the development of the performing arts in Rwanda through what Karemera refers to as kamakaze theatre productions in public venues, the biblio-bus, and scheduled cultural events including theatrical readings and performances at the centre. The examples note the importance of addressing socio-political tensions like language through inclusive approaches and to influence the development of the performing arts through widespread public access and literacy development. In regards to resistant acts, Ishyo presents a strong example of artists willing to question current governmental practices using comedy and adaptations to make critical social commentary on contemporary issues. Scott states:

Finally, what permits subordinate groups to undercut the authorized cultural norms is the fact that cultural expression by virtue of its polyvalent symbolism and metaphor lends itself to disguise. By the subtle use of codes one can insinuate into a ritual, a pattern of dress, a song, or story, meanings that are accessible to one intended audience and opaque to another audience the actors wish to exclude. Alternatively, the excluded (and in this case, powerful) audience may grasp the seditious message in the performance but find it difficult to react because that sedition is clothed in terms that also can lay claim to perfectly innocent construction. (158)

Although there have been notable restrictions on any form of criticism aimed at the government in Rwanda, Ishyo has been successful in developing platforms for open discourse using the fictional frame of theatre. 


\section{Conclusion}

The case study examples provide several different frameworks for resistant acts to decode social performances of power (as constructed through gacaca). Borrowing from Scott, "faltered speech" requires a more rigorous analysis of divergent discourses and to learn the nuanced dialects and codes within a dominant structure. The initial case study illustrated how the social performance of gacaca itself was used to deconstruct the power structures that it maintained based on notions of guilt, forgiveness and confession. The second case study exemplified how theatre scripts can rewrite the predominant government narrative, providing alternative actors and embedding the form with contemporary socio-political issues (otherwise censored). The last case study provides an exemplary form of resistance, under the watchful eye of the government. The future development of Ishyo and the risky inclusion of narratives that question issues like government corruption into open public discourse through the fictional frame of theatre, will need to be further monitored in regards to financial support, government access, and licensing. However, Ishyo works with international artists and audiences that serve as a united community to advocate for Rwandan artists who seek alternative speech acts, beyond faltered speech into articulated utterances for Rwandan audiences and beyond. Although speech acts might be tightly controlled in Rwanda, the support of external partners and audiences allows for greater risk taking using theatre for public discourse. What is often available, however, is what they have been able to introduce in muted or veiled form into the public transcript. I believe that the practices presented by Karemera effectively begin to integrate the hidden transcript into the public transcript. In this way, theatrical frames have provided an alternative route for hidden transcripts to emerge, developing a space and platform for the reconstruction of post-genocide Rwanda. 


\section{Notes}

1. Tribunal plays have been staged at the Tricycle Theatre in Kilburn, London using verbatim theatre to address public inquiries like the Bloody Sunday trials. However, the use of theatre to address genocide through the gacaca courts and affiliated theatre productions is markedly different due to the lived post-conflict experience of its actors and audiences in Rwanda and the short time-span between the 1994 genocide and subsequent gacaca courts alongside theatrical productions.

2. Ananda Breed, 'Performing the Nation: Theatre in Post-Genocide Rwanda' The Drama Review 52 (1): 32-50. The term Rwandanicity was used by Frank K. Rusagara in the newspaper article "Gacaca: Rwanda's truth and reconciliation authority," The New Times, 16 May 2005, p.1.

3. For more information about grassroots organisations see Breed, "Performing the Nation," pp. 33-50.

4. See Carina Tertsakian about the roles that prisoners performed in prison and the bartering of crimes for reduced sentences.

5. Filip Reyntjens notes, '[o]ver the post-1994 period, it (Rwanda) has relied on international aid for about 25 percent of its GDP and over 50 percent of its budget.

\section{Works Cited}

Alexander, Jeffrey C. Performance and Power. Cambridge: Polity, 2011. Print.

Breed, Ananda. "Performing the Nation: Theatre in Post-Genocide Rwanda." The Drama Review 52:1 (2008): 32-50. Print.

Campioni, Maddalena, and Patrick Noack. Rwanda Fast Forward: Social, Economic, Military and Reconciliation Prospects. Hampshire: Palgrave Macmillan, 2012. Print.

Eltringham, Nigel. Accounting for Horror: Post-Genocide Debates. London: Pluto, 2004. Print.

Fischer-Lichte, Erika. The Transformative Power of Performance: A New Aesthetics. New York: Routledge, 2008. Print.

Humphreys, Stephen. "Legalizing Lawlessness: On Giorgio Agamben's State of Exception." The European Journal of International Law 17.3 (2006): 677-687. Print.

Jamar, Astrid. "Deterioration of Aid Coordination in Gacaca Implementation: Dealing with the Past for a Better Future?" Rwanda Fast Forward: Social, Economic, Military and Reconciliation Prospects. Eds. Maddalena Campioni and Patrick Noack.

Hampshire: Palgrave Macmillan. 85. Print.

Karemera, Carole. Personal Interview. 6 Apr. 2013.

Mgbako, Chi. "Ingando Solidarity Camps: Reconciliation and Political Indoctrination in Post-Genocide Rwanda." Harvard Human Rights Journal 18 (2005): 201-224. Print Mughisha, Stevenson. "Illiteracy Rate Decreases." The New Times. 14 May 2012. Print. Mukayiranga, Laurence. Personal Interview. 13 April 2010. 
National Unity and Reconciliation Commission. 2012. Web. 1 Sept. 2007.

Organic Law No. 16/2004 of 19/6/2004. Article 54. p. 15. Print.

Pottier, Johan. Re-Imagining Rwanda: Conflict, Survival and Disinformation in the Late Twentieth Century. Cambridge: Cambridge UP, 2002. Print.

Reynolds, Dee and Matthew Reason. Kinesthetic Empathy in Creative and Cultural Practices. Bristol: Intellect, 2012. Print.

Reyntjens, Filip. "Constructing the Truth, Dealing with Dissent, Domesticating the World: Governance in Post-Genocide Rwanda." African Affairs. 110.438 (2010): 1-34. Print.

Rusagara, Frank K. "Gacaca: Rwanda's truth and reconciliation authority." The New Times. 16 May 2005. Print.

"Rwanda." Aid Effectiveness 2011: Progress in Implementing the Paris De claration - Volume II Country Chapters. Organization for Economic Co-operation and Development. 9 Sept. 2012. Web. 10 July 2013.

Scott, James C. Domination and the Arts of Resistance. New Haven: Yale UP, 1990. Print.

Shaw, Rosalind and Lars Waldorf. Localizing Transitional Justice: Interventions and Priorities After Mass Violence. Stanford: Stanford UP, 2010. Print.

Straus, Scott and Lars Waldorf. Remaking Rwanda: State Building and Human Rights after Mass Violence. Madison: U of Wisconsin P, 2011. Print.

Tertsakian, Carina. Le Chateau: The Lives of Prisoners in Rwanda. London: Arves, 2008. Print. 